\title{
Prey dominance shapes trophic structure of the northern California Current pelagic food web: evidence from stable isotopes and diet analysis
}

\author{
Todd W. Miller ${ }^{1, *}$, Richard D. Brodeur ${ }^{2}$, Greg Rau ${ }^{3}$, Koji Omori ${ }^{1}$ \\ ${ }^{1}$ Center for Marine Environmental Studies (CMES), Ehime University, 2-5 Bunkyo cho, Matsuyama, Ehime 790-8577, Japan \\ ${ }^{2}$ NOAA, Northwest Fisheries Science Center, Hatfield Marine Science Center, Newport, Oregon 97365, USA \\ ${ }^{3}$ Institute of Marine Sciences, University of California, Santa Cruz, California 95064, USA
}

\begin{abstract}
Eastern boundary current (EBC) upwelling zones are among the most productive of marine ecosystems globally and have been generalized in terms of their food web structure. Little empirically based evidence exists to suggest that there is any one form of trophic control of EBC systems and, because of logistical constraints, knowledge of food web structure is limited in these large marine ecosystems. To determine principal trophic links within the pelagic food web, we combined stable isotope and diet analysis of 21 dominant species of nekton found within the northern California Current, a highly productive EBC upwelling ecosystem. Samples of nekton and zooplankton were collected in June and August 2000 and 2002 from the shelf-slope waters of northern California to Washington. Results showed most nekton consumed mixed diets of zooplankton and larval-juvenile or adult fishes, indicating the importance of omnivory in this system. Euphausiids were overwhelmingly the most prevalent zooplankton taxa in the diets of nekton across multiple trophic levels, accounting for $>50 \%$ of the index of relative importance in 10 of 21 nekton species analyzed. Nitrogen stable isotopes $\left(\delta^{15} \mathrm{~N}\right)$ reflected trophic patterns observed in the diets, with most nekton species $(\sim 62 \%)$ falling between trophic levels $(\mathrm{TL})$ of full zooplanktivores $(\mathrm{TL}=3)$ and full piscivores $(\mathrm{TL}=4)$. The prevalence of omnivory observed here is probably due to high primary production that supports an abundance of large zooplankton prey, such as euphausiids, which may be a more available prey resource for a broad range of predators. A modification of this form of bottom-up control, termed bottom-up omnivory, is presented.
\end{abstract}

KEY WORDS: Pelagic $\cdot$ Food web $\cdot$ Stable isotopes $\cdot$ Diet $\cdot$ California Current

\section{INTRODUCTION}

Eastern boundary current (EBC) upwelling zones are among the most productive of coastal systems globally and have been central to the discussion of what mechanisms regulate marine pelagic ecosystems (for example Cury et al. 2000, Yodzis 2000, Ware \& Thomson 2005). In EBC systems, strong seasonal upwelling drives high primary and higher trophic level production (Cury et al. 1998, Chavez et al. 2003) that results in a nekton community in which much of the biomass is represented by only a few species feeding at or near the secondary consumer level (Cury et al. 2000). Dramatic shifts in upwelling and primary productivity, such as those that occur during El Niño and La Niña events, cause major changes in the zooplankton community (Keister et al. 2005, Mackas et al. 2007) that directly affect fish (Brodeur \& Pearcy 1992) and marine birds (Ainley et al. 1996). These biological responses portray the importance of overall trophic structure and trophic relationships in EBC systems, which have been generalized in terms of bottom-up (Cury \& Shannon 2004, Ware \& Thomson 2005) and 'wasp-waist' or sideways (Cury et al. 2000) control. Undoubtedly multiple processes are at play; however, few studies have examined aspects of the marine pelagic trophic spectrum of EBC systems, where the number and strength of trophic linkages may influence community response to climate change and increased fishing pressure (Yodzis 2000). 
Trophic relationships within EBC systems have been examined through diet analysis (Brodeur \& Pearcy 1992, Shannon et al. 2003, Tam et al. 2006) as well as fisheries catch and correlation analyses (Shannon et al. 2003, Ware \& Thomson 2005, Hutchings et al. 2009). Although these methods have provided important ecological information on trophic strucuture, they offer limited interpretation of specific trophic interactions. Stomach content analyses can provide detailed information on the feeding behavior of an organism, including the number and size of prey species, and quantity of prey consumed. A major limitation of stomach content analyses is that it only provides a recent observation of feeding; therefore, large sample sizes collected over time are required to capture variation in diet. Moreover, stomach content analyses fail to capture what prey were assimilated into predator growth.

Alternatively, stable isotope analysis using ratios of carbon $\left({ }^{13} \mathrm{C} /{ }^{12} \mathrm{C}\right)$ and nitrogen $\left({ }^{15} \mathrm{~N} /{ }^{14} \mathrm{~N}\right)$ is now a common tool in elucidating relative trophic position and source of base production of an organism (Post 2002). The stable isotope approach is based on an organism's differential retention of the heavier isotope over the lighter one relative to its diet. Over time, the relative distribution of isotope ratio values effectively acts as a time-averaged signature of the organism's assimilated diet (Peterson \& Fry 1987, Post 2002). The trophicmediated difference in retention of the heavier and lighter forms is generally termed trophic fractionation or trophic enrichment (Peterson \& Fry 1987) and can effectively be used to examine relative trophic position. Stable isotopes are measured as the ratio of the heavy $\left({ }^{15} \mathrm{~N}\right)$ to the lighter $\left({ }^{14} \mathrm{~N}\right)$ isotope of an element with the following equation: $\delta X=\left[\left(R_{\text {sample }} / R_{\text {standard }}\right)-\right.$ $1] \times 10^{3}$ where $X$ is ${ }^{15} \mathrm{~N}$ and $R$ is the ratio of the heavy to the light isotope (Peterson \& Fry 1987). For nitrogen, a predator preferentially retains the heavier $\left({ }^{15} \mathrm{~N}\right)$ isotope over the lighter $\left({ }^{14} \mathrm{~N}\right)$ one in its diet, with each trophic level accounting for an approximate enrichment of $3.4 \%$ relative to its prey (Post 2002). A limitation of stable isotopes is that they lack the detailed descriptive power provided by diet analyses, a fundamental component in accurately describing food webs. Ideally, a method using both diet and stable isotopes can provide a more in-depth measure of trophic relationships because they are complementary in describing the specific prey consumed while measuring assimilated diet over time.

The northern California Current (NCC) ecosystem resides along the western shelf of North America approximately between Cape Mendocino, California, $\left(40^{\circ} 10^{\prime} \mathrm{N}\right)$ and southern Vancouver Island, British Columbia, $\left(49^{\circ} 11^{\prime} \mathrm{N}\right)$. The upwelling zone of the NCC exhibits high seasonal upwelling and subsequent primary and secondary production (Checkley \& Barth
2009) and is associated with high abundances of sardines, anchovies, mackerels and hakes (Brodeur et al. 2003, 2005). The persistence and intensity of upwelling is highly variable over scales of years to decades (Smith et al. 2001), which has been related to corresponding shifts in zooplankton (Roemmich \& McGowan 1995) and the abundance of some nekton species (Brodeur et al. 2003, 2005, Emmett et al. 2006). This large-scale ecosystem variability underlies the importance of understanding trophic relationships that may be a requisite for ecosystem-based management.

The goal of the present study was to examine the trophic structure of a large marine ecosystem, the NCC pelagic food web, by applying a dual approach of stable isotopes and conventional dietary analysis. We used $\delta^{15} \mathrm{~N}$ to examine the relative trophic positions among many of the dominant nekton and zooplankton of the NCC ecosystem and stomach content analysis of nekton and agglomerative hierarchical cluster analysis of diet data to reveal trophic links associated with their isotope-derived trophic positions. We then used $\delta^{13} \mathrm{C}$ as a delineator of cross-shelf production as described by Miller et al. (2008). Certain dominant prey groups that shape the NCC food web are presented, and their importance is discussed.

\section{MATERIALS AND METHODS}

Field collection and laboratory analysis. Nekton and zooplankton samples used for this study were collected during Global Ocean Ecosystems Dynamics (GLOBEC) cruises in the northeast Pacific Ocean during June and August 2000 and 2002. Sampling occurred along a series of transects across the shelf between Crescent City, California, (41 $\left.54.0^{\prime} \mathrm{N}\right)$ and Newport, Oregon, $\left(44^{\circ} 39.0^{\prime} \mathrm{N}\right)$; sampling stations are described in Miller et al. (2008) for 2002 and sampling sites in 2000 were collected from the same transects. At each station, nekton were collected with a Nordic264 rope trawl (30 $\mathrm{m}$ wide by $18 \mathrm{~m}$ deep) towed for 30 min. Macrozooplankton, such as adult euphausiids and larval-juvenile fish, were occasionally retained in the fine mesh liner of the trawl and were collected for isotope analysis. Smaller zooplankton $(<5 \mathrm{~mm})$ were collected with surface neuston hauls $\left(1 \mathrm{~m}^{2}\right.$ mouth, 335 $\mu \mathrm{m}$ mesh). Particulate organic matter (POM) samples were collected with a Niskin bottle sampled at $3 \mathrm{~m}$ depth, prefiltered through a $64 \mu \mathrm{m}$ sieve to remove higher trophic level zooplankton and filtered through a $47 \mathrm{~mm}$ glass fiber filter $(\sim 0.7 \mu \mathrm{m})$ at $<0.04 \mathrm{MPa}$. After their collection, all nekton, zooplankton and POM samples were immediately frozen $\left(-20^{\circ} \mathrm{C}\right)$ onboard ship and later taken to the laboratory for processing. 
Laboratory processing for stable isotope analysis of fish and zooplankton is described in Miller et al. (2008). Briefly, a portion of the anterior-dorsal muscle tissue of fish and squid was removed and used for isotope analyses. Zooplankton samples were thawed in the lab and sorted into groups based on the dominant prey taxa observed in nekton diets. Grouping was based on diet data from Miller \& Brodeur (2007) as follows: copepods (e.g. Calanus, Metridia and Acartia), euphausiids (Euphausia pacifica and Thysanoessa spinifera), crab megalopae (Cancer oregonensis/productus, C. magister and C. antennarius/gracilis), other decapod larval stages and larval and juvenile fishes. Except for small copepods, which required multiple individuals for isotope analysis, all other taxa were measured as individuals.

Nitrogen $\left(\delta^{15} \mathrm{~N}\right)$ and carbon $\left(\delta^{13} \mathrm{C}\right)$ stable isotopes were analyzed following the methods and instrumentation described in Miller et al. (2008); $\delta^{13} \mathrm{C}$ was lipidnormalized and the trophic level adjusted (hereafter denoted as $\delta^{13} \mathrm{C}_{\mathrm{TL}}^{\prime}$ ). The $\delta^{13} \mathrm{C}_{\mathrm{TL}}^{\prime}$ values were used to denote relative placement along the shelf-slope production gradient (Miller et al. 2008), whereas $\delta^{15} \mathrm{~N}$ was used to measure trophic level and relative trophic position. To add to the trophic spectrum, we included mean and SE isotope values of $\delta^{15} \mathrm{~N}$ and $\delta^{13} \mathrm{C}$ from Bosley et al. (2004) for hyperiid amphipods from the same region because they are important zooplankton prey to many nekton fish species (Miller \& Brodeur 2007). For those species from which adequate sample sizes were obtained ( $\mathrm{n} \geq 5$ ), a 2-tailed $t$-test $(\alpha=0.05)$ was used to compare seasonal (June and August) and interannual (2000 and 2002) differences in $\delta^{15} \mathrm{~N}$ and $\delta^{13} \mathrm{C}_{\mathrm{TL}}^{\prime}$. For 2000, jack mackerel Trachurus symmetricus and whitebait smelt Allosmerus elongatus were compared between June and August, and for 2002 comparisons were made from POM, copepods and nekton of market squid Loligo opalescens, Pacific herring Clupea pallasii, Pacific sardine Sardinops sagax, Pacific saury Cololabis saira, jack mackerel, surf smelt Hypomesus pretiosus and whitebait smelt. Between-year comparisons by month (June and August) were made between June 2000 and August 2002 for market squid, jack mackerel, Pacific herring, surf smelt and whitebait smelt, and between August 2000 and August 2002 for 4 nekton species (jack mackerel, Pacific saury, Pacific sardine, and whitebait smelt). This allowed for moderate assessment of potential intra- and interannual variation, which may occur between spring and summer production.

A detailed description of the methods applied for diet analysis of nekton are in Miller \& Brodeur (2007). Index of relative importance (IRI) was calculated for each prey of each nekton species using the percent number of prey $(\% \mathrm{~N})$, percent weight contribution to the diet $(\% \mathrm{~W})$ and the percent frequency of occurrence (\% O) (Pinkas et al. 1971). Percent IRI (Cortés 1997) for prey $j$ was derived by means of the following equations:

$$
\begin{aligned}
\mathrm{IRI}_{i} & =\% \mathrm{O}_{i}\left(\% \mathrm{~N}_{i}+\% \mathrm{~W}_{i}\right) \\
\mathrm{IRI}_{i} & =\left(100 \times \mathrm{IRI}_{i}\right) / \Sigma_{j=1}^{n} \mathrm{IRI}_{j}
\end{aligned}
$$

where $i$ is one of $j$ th prey items. Because some prey items could not be individually enumerated or identified to species, we aggregated several prey taxa into higher taxonomic or functional groups representing appendicularians, amphipods (predominantly Gammaridea and Hyperiidea), copepods, euphausiid eggs, euphausiid furcilia, Thysanoessa spinifera, Euphausia pacifica, decapod larvae-juveniles, Cancer magister megalopae, Osteichthyes larvae and Osteichthyes adults. Some prey categories, such as phytoplankton, gelatinous zooplankton, crustacean zooplankton, unidentified fish parts and other unidentified material, were excluded from analysis of IRI owing to the problems with enumerating individual prey. The \%W of material not included in the \%IRI values were generally less than $10 \%$ of the total \%W of each nekton species diet with the exception of the following ( $\% \mathrm{~W}$ of total excluded): Pacific saury (15\%), Pacific sardine $(20 \%)$ and surf smelt (14\%).

Data analyses. We examined trophic structure by first applying agglomerative hierarchical cluster analysis (AHCA) to diet data (\%IRI) and then measuring the mean trophic enrichment in ${ }^{15} \mathrm{~N}$ from AHCA-based nekton trophic groups and their prey. AHCA was done by forming a predator-prey matrix based on \%IRI contribution of major prey taxa (columns) to predator diet (rows). Raw data were then transformed using an arcsine square root transformation to improve normality in the proportional data. Cluster analysis was performed using PcOrd (v. 4.1, MjM Software) using a flexible beta linkage method $(\beta=-0.250)$ and relative Sørensen (Kulcynski) distance measure. Cluster groups were distinguished by choosing an appropriate cutoff level in the dendrograms based on biological meaning while maintaining a moderate-to-high percentage of information retained (>40\%). Cluster groupings were then described in terms of their ranked dominant prey, defined as the top prey categories, which together added up to $\geq 70 \%$ IRI of the diet.

We calculated the number of trophic levels (TL) and trophic position of an individual organism following Post's (2002) notation: trophic position (TP) $=\lambda+$ $\left(\delta^{15} \mathrm{~N}_{\text {secondary consumer }}-\delta^{15} \mathrm{~N}_{\text {base }}\right) / \Delta_{\mathrm{n}}$, where $\lambda$ is the trophic position of the organism used to establish the $\delta^{15} \mathrm{~N}_{\text {baser }}$ $\delta^{15} \mathrm{~N}_{\text {secondary consumer }}$ is the $\delta^{15} \mathrm{~N}$ of the nekton consumer and $\Delta_{\mathrm{n}}\left(\Delta \delta^{15} \mathrm{~N}\right)$ is the enrichment in $\delta^{15} \mathrm{~N}$ per trophic level. For $\Delta \delta^{15} \mathrm{~N}$ we used the value of $3.4 \%$ per TL from 
Post (2002). The $\delta^{15} \mathrm{~N}_{\text {base }}$ in this case was established by taking the mean $\delta^{15} \mathrm{~N}$ of crustacean zooplankton (mainly copepods and decapod larvae) and setting $\lambda=$ 2 because zooplankton are primary consumers.

\section{RESULTS}

The total range of $\delta^{15} \mathrm{~N}$ from base production (POM, mean $\delta^{15} \mathrm{~N}=6.1$ ) to highest nekton predator-soupfin shark Galeorhinus galeus-was $9.4 \%$, indicating a total of $\sim 3.7 \mathrm{TL}$; the addition of $\delta^{15} \mathrm{~N}$ values of northern sea lion Eumetopias jubatus from Sydeman et al. (1997) increased the total number of TLs to 5.0. Primary con- sumers (zooplankton, $\delta^{15} \mathrm{~N}_{\text {base }}=9.4, \mathrm{SE}=0.06$ ) were enriched by approximately $3.3 \%$ over POM (Table 1 , Fig. 1). The euphausiid, Thysanoessa spinifera, and hyperiid amphipods were the only zooplankton with $\delta^{15} \mathrm{~N}$ values noticably higher than those of other zooplankton taxa, with respective values of approximately $4.0 \%$ (TL 2.3) and 4.5\%o (TL 2.4), respectively, above POM. Comparison of $\delta^{15} \mathrm{~N}$ values between June and August sampling showed no significant difference $(p>0.05)$ in POM, copepods and nekton of Pacific sardine, Pacific herring, jack mackerel and whitebait smelt. Significant differences were observed between nekton of market squid $\left(\mathrm{p}=0.002, t(\mathrm{df}=36)=3.2\right.$, mean $\delta^{15} \mathrm{~N}$ difference $=$ $+0.3 \%$ in June), surf smelt $(\mathrm{p}=0.02, t(15)=2.6$, mean

Table 1. Summary of $\delta^{15} \mathrm{~N}$ values (June and August 2000 and 2002 combined) of POM, zooplankton and nekton from the northern California Current ecosystem. Trophic position (TP) was measured using the general equation from Post (2002). All taxa are adult stage unless otherwise noted by the following abbreviations. l: larval stage; l-j: larval-juvenile stage; j: juvenile; sy: sub yearling; y: yearling

\begin{tabular}{|c|c|c|c|c|}
\hline Taxon & Abbreviation & $\mathrm{n}$ & $\mathrm{TP}$ & $\begin{array}{c}\delta^{15} \mathrm{~N} \\
\text { average (SE) }\end{array}$ \\
\hline \multicolumn{5}{|l|}{ POM } \\
\hline Shelf (shelf, depth $<150 \mathrm{~m}$ ) & POM-sh & 29 & 1.2 & $6.5(0.4)$ \\
\hline Slope (slope, depth > $150 \mathrm{~m}$ ) & POM-sl & 39 & 1.0 & $5.7(0.2)$ \\
\hline \multicolumn{5}{|l|}{ Zooplankton } \\
\hline Copepoda (shelf, depth < $150 \mathrm{~m}$ ) & cope-sh & 26 & 2.0 & $9.1(0.1)$ \\
\hline Copepoda (slope, depth $>150 \mathrm{~m}$ ) & cope-sl & 19 & 2.0 & $9.4(0.3)$ \\
\hline Decapoda $(1-j)$, shelf & dec-sh & 30 & 2.1 & $9.5(0.2)$ \\
\hline Decapoda (l-j), slope & dec-sl & 36 & 2.1 & $9.4(0.1)$ \\
\hline Euphausia pacifica & epac & 11 & 2.1 & $9.4(0.1)$ \\
\hline Thysanoessa spinifera & tspin & 17 & 2.3 & $10.1(0.1)$ \\
\hline \multicolumn{5}{|l|}{ Nekton } \\
\hline Market squid, Loligo opalescens & mks & 79 & 3.0 & $12.8(0.1)$ \\
\hline Chum salmon (j), Oncorhynchus keta & chuj & 1 & 3.7 & 15.1 \\
\hline Chum salmon & chu & 2 & 3.0 & $12.6(0.3)$ \\
\hline Coho salmon (y), O. kisutch & coy & 69 & 3.3 & $13.5(0.3)$ \\
\hline Coho salmon & coa & 19 & 3.3 & $13.5(0.3)$ \\
\hline Chinook salmon (s), O. tshawytscha & chs & 20 & 3.3 & $13.7(0.3)$ \\
\hline Chinook salmon (y) & chy & 76 & 3.5 & $14.3(0.1)$ \\
\hline Chinook salmon & cha & 60 & 3.5 & $14.2(0.1)$ \\
\hline Cutthroat trout, O. clarkii & cut & 8 & 3.6 & $14.6(0.2)$ \\
\hline Steelhead trout (j), O. mykiss & stj & 4 & 3.2 & $13.4(0.4)$ \\
\hline Rex sole (l), Errex zachirus & rexl & 2 & 2.8 & $11.9(0.3)$ \\
\hline Rockfish (pelagic, (j)), Sebastes spp. & rfj & 24 & 2.9 & $12.3(0.1)$ \\
\hline Spiny dogfish, Squalus acanthias & spdf & 16 & 3.0 & $12.6(0.1)$ \\
\hline Pacific sardine (1), Sardinops sagax & sarj & 25 & 2.7 & $11.7(0.2)$ \\
\hline Pacific sardine & sard & 58 & 2.9 & $12.2(0.1)$ \\
\hline Pacific herring, Clupea pallasii & herr & 68 & 3.2 & $13.3(0.1)$ \\
\hline Northern anchovy, Engraulis mordax & anch & 17 & 3.1 & $12.8(0.1)$ \\
\hline Pacific sand lance, Ammodytes hexapterus & sand & 34 & 2.7 & $11.6(0.1)$ \\
\hline Pacific hake, Merluccius productus & hake & 6 & 3.3 & $13.7(0.1)$ \\
\hline Sablefish (j), Anoplopoma fimbria & sabj & 14 & 3.3 & $13.5(0.1)$ \\
\hline Surf smelt, Нypomesus pretiosus & $\mathrm{ssm}$ & 46 & 3.2 & $12.8(0.2)$ \\
\hline Whitebait smelt, Allosmerus elongatus & wbsm & 61 & 3.3 & $13.7(0.1)$ \\
\hline Pacific saury, Cololabis saira & saur & 41 & 3.1 & $12.8(0.1)$ \\
\hline Pacific mackerel, Scomber japonicus & $\mathrm{pm}$ & 3 & 3.4 & $13.9(0.1)$ \\
\hline Jack mackerel, Trachurus symmetricus & $\mathrm{jm}$ & 45 & 3.6 & $14.5(0.1)$ \\
\hline Soupfin shark, Galeorhinus galeus & ssk & 1 & 3.8 & 15.4 \\
\hline Blue shark, Prionace glauca & bsk & 10 & 3.6 & $14.7(0.2)$ \\
\hline
\end{tabular}




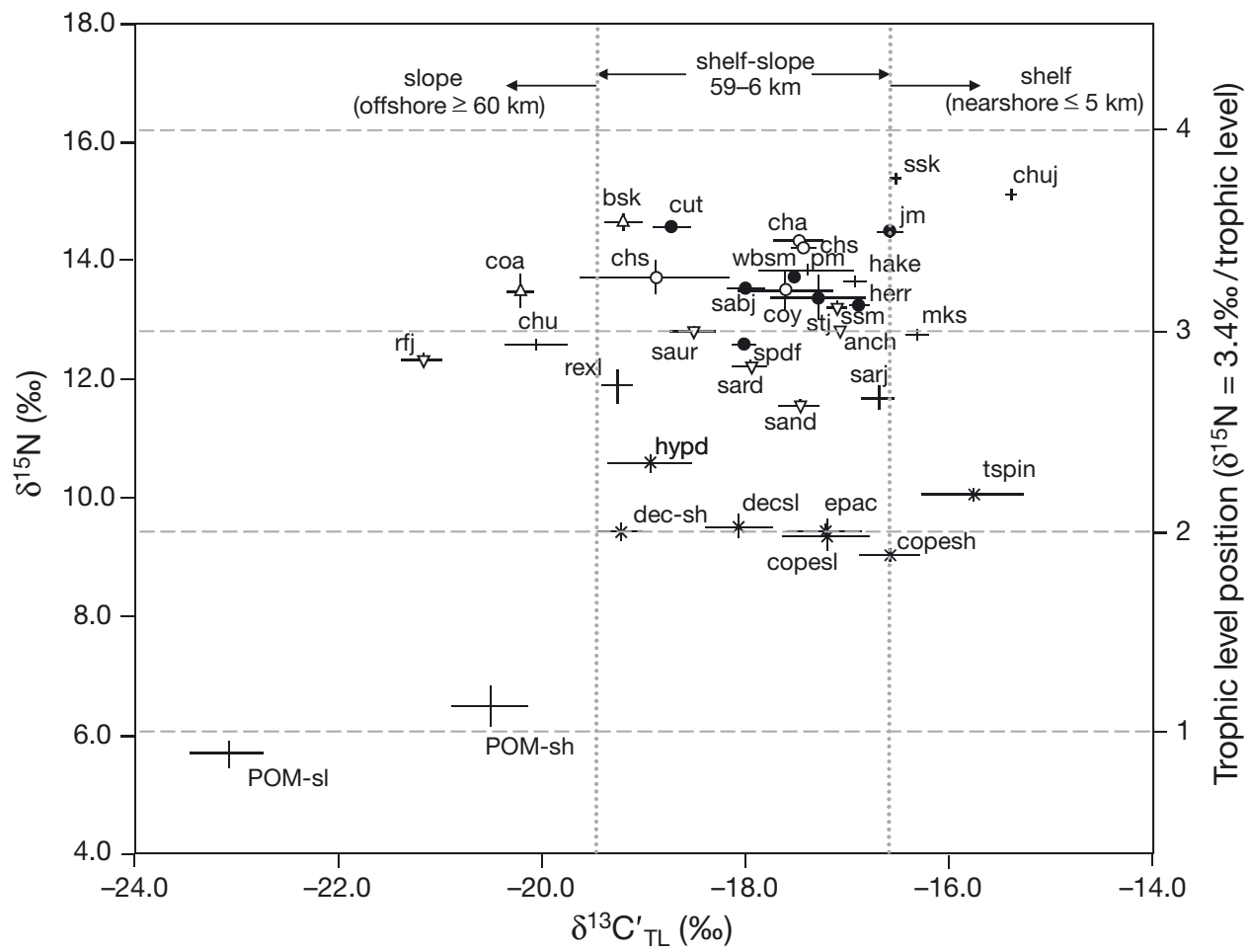

Fig. 1. Mean $( \pm \mathrm{SE}) \delta^{13} \mathrm{C}$ and $\delta^{15} \mathrm{~N}$ of zooplankton and nekton from the northern California Current ecosystem collected during June and August of 2000 and 2002. Trophic levels are based on $\Delta \delta^{15} \mathrm{~N} \pm 3.4 \%$ from mean $\delta^{15} \mathrm{~N}$ of copepods and decapod larvae combined. Nekton trophic groups based on cluster analysis of diets (\% IRI, see Fig. 2) are shown as circles $(O, \bullet)$, and triangles $(\nabla, \Delta)$. Points with an $\times$ denote zooplankton and, excluding POM, points with no symbol are nekton that were not included in the cluster analysis. Hyperiid amphipod values (hypd) are from Bosley et al. (2004). Nearshore and offshore demarcations are based on $\delta^{13} \mathrm{C}^{\prime} \mathrm{TL}$ values from Miller et al. (2008), which were lipid normalized (') and trophic-level corrected (TL). See Table 1 for abbreviations for all other taxa

$\delta^{15} \mathrm{~N}$ difference $=+0.7 \%$ in August) and Pacific saury $\left(\mathrm{p}=0.02, t(29)=2.5\right.$, mean $\delta^{15} \mathrm{~N}$ difference $=+0.5 \%$ in August). Comparisons between years by season (June and August) of market squid, jack mackerel, Pacific herring, surf smelt, whitebait smelt, Pacific saury and Pacific sardine only showed a significant difference between June 2000 and 2002 for jack mackerel ( $p>0.01$, $t(16)=4.2$, mean $\delta^{15} \mathrm{~N}$ difference $=+0.5 \%$ in 2002) and Pacific herring $\left(p>0.01, t(30)=2.8\right.$, mean $\delta^{15} \mathrm{~N}$ difference $=+0.5 \%$ in 2002). From between June and August sampling, $\delta^{13} \mathrm{C}_{\mathrm{TL}}^{\prime}$ values showed significant differences in Pacific saury $\left(p>0.01, t(29)=3.2\right.$, mean $\delta^{13} \mathrm{C}^{\prime}{ }_{\mathrm{TL}}$ difference $=+0.9 \%$ in August) and whitebait smelt ( $\mathrm{p}>$ $0.01, t(23)=5.6$, mean $\delta^{13} \mathrm{C}_{\mathrm{TL}}^{\prime}$ difference $=+0.7 \%$ in August). Significant differences between years by season in $\delta^{13} \mathrm{C}_{\mathrm{TL}}^{\prime}$ were observed for market squid $(\mathrm{p}>0.01$, $t(40)=3.2$, mean $\delta^{13} \mathrm{C}^{\prime}{ }_{\mathrm{TL}}$ difference $=+0.9 \%$ in 2002), Pacific sardine $\left(\mathrm{p}=0.01, t(27)=2.6\right.$, mean $\delta^{13} \mathrm{C}_{\mathrm{TL}}{ }_{\mathrm{T}}$ difference $=+0.7 \%$ in 2000), Pacific herring $(\mathrm{p}>0.01, t(44)=$ 7.5 , mean $\delta^{13} \mathrm{C}_{\mathrm{TL}}^{\prime}$ difference $=+1.3 \%$ in 2002), whitebait $\left(\mathrm{p}>0.01, t(23)=4.7\right.$, mean $\delta^{13} \mathrm{C}_{\mathrm{TL}}^{\prime}$ difference $=$ $+0.4 \%$ in 2002) and surf smelt $(\mathrm{p}>0.01, t(31)=6.3$, mean $\delta^{13} \mathrm{C}^{\prime}{ }_{\mathrm{TL}}$ difference $=+0.9 \%$ in 2002).
From agglomerative hierarchical cluster analysis (AHCA) of diets and integration with $\delta^{15} \mathrm{~N}$ of 21 pelagic nekton species, 13 of 21 species ( 65\%, Table 1$)$ were found between TL 3.2 and 3.8 (Fig. 1). When all nekton were measured for $\delta^{15} \mathrm{~N}$ no species exceeded TL 3.8, and 17 of the 28 species analyzed (62\%) were found between TL 3.2 and 3.8. Based on the analysis of the nekton in the diet, much of this pattern was reflected in the AHCA of diet data with general trophic groups expressing mixed diets of adult and larval-juvenile fish and zooplankton (Figs. 2 \& 3, Table 2). Zooplankton included euphausiids (predominantly adults and eggs), decapod larvae and copepods (Figs. 2 \& 3, Table 2). In particular, the euphausiids Thysanoessa spinifera and Euphausia pacifica were the most widely consumed taxa across multiple trophic levels, with 10 of 21 species examined having $>50 \%$ IRI values of euphausiids as prey (Table 2, Fig. 3).

The most picivorous fishes were adult blue shark Prionace glauca and coho salmon Oncorhynchus kisutch (Cluster Group II in Table 2, Figs. 2 \& 3), with respective \%IRI values for fish of 62.3 and $22.8 \%$. However, in both species a substantial proportion of the diet con- 


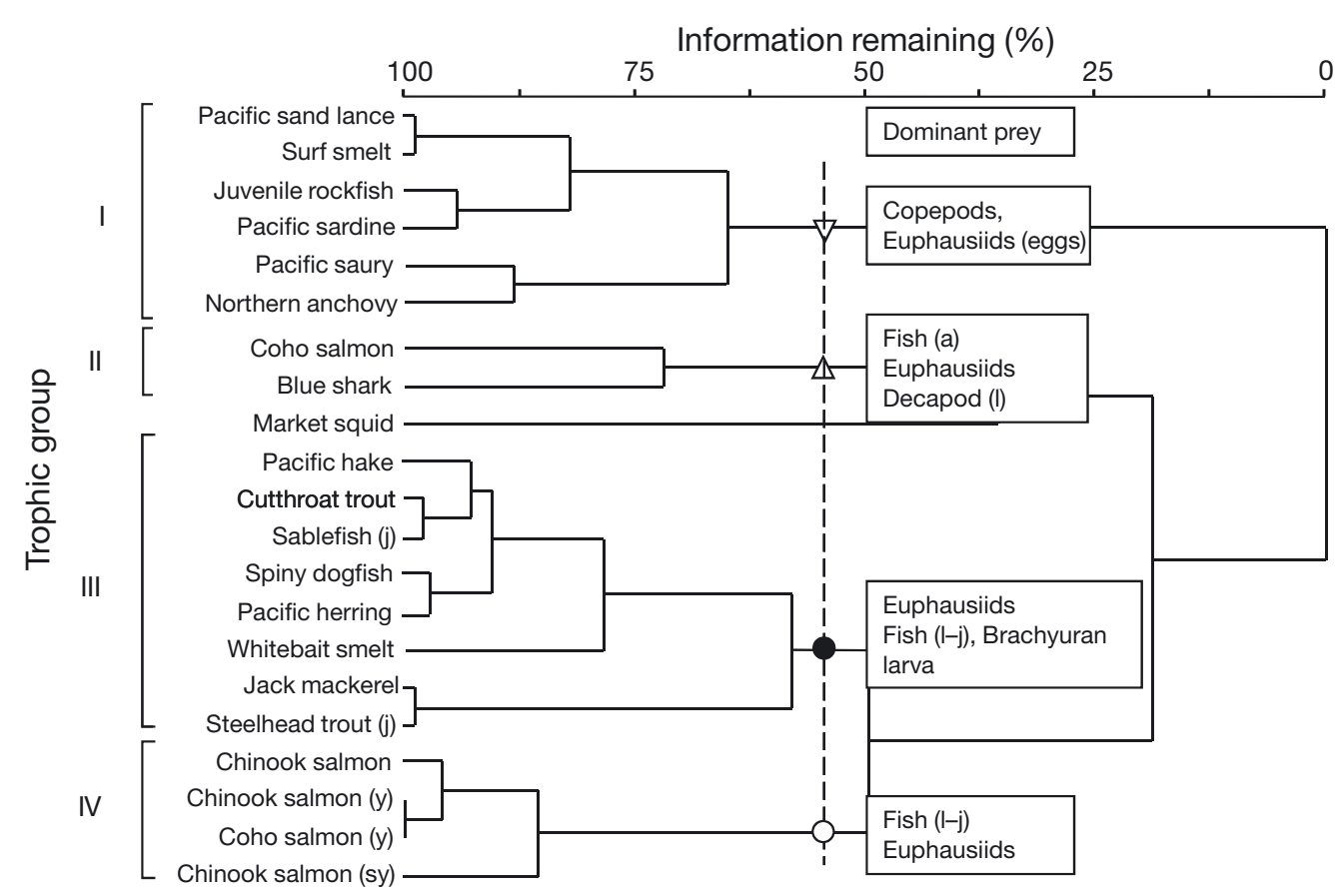

Fig. 2. Cluster analysis dendrogram of nekton species based on percent index of relative importance (\% IRI) of diet. Trophic groups are designated by the dashed line at the cutoff level of approximately $55 \%$ information remaining; different symbols are referenced to the stable isotope plot in Fig. 1. Dominant prey are based on the top taxa representing $\geq 70 \%$ IRI of the diet. Life-history stages are adult, unless otherwise indicated as the following: sy: sub yearling; y: yearling; l: larval; j: juvenile; l-j: larval-juvenile stage; a: adult (prey only)

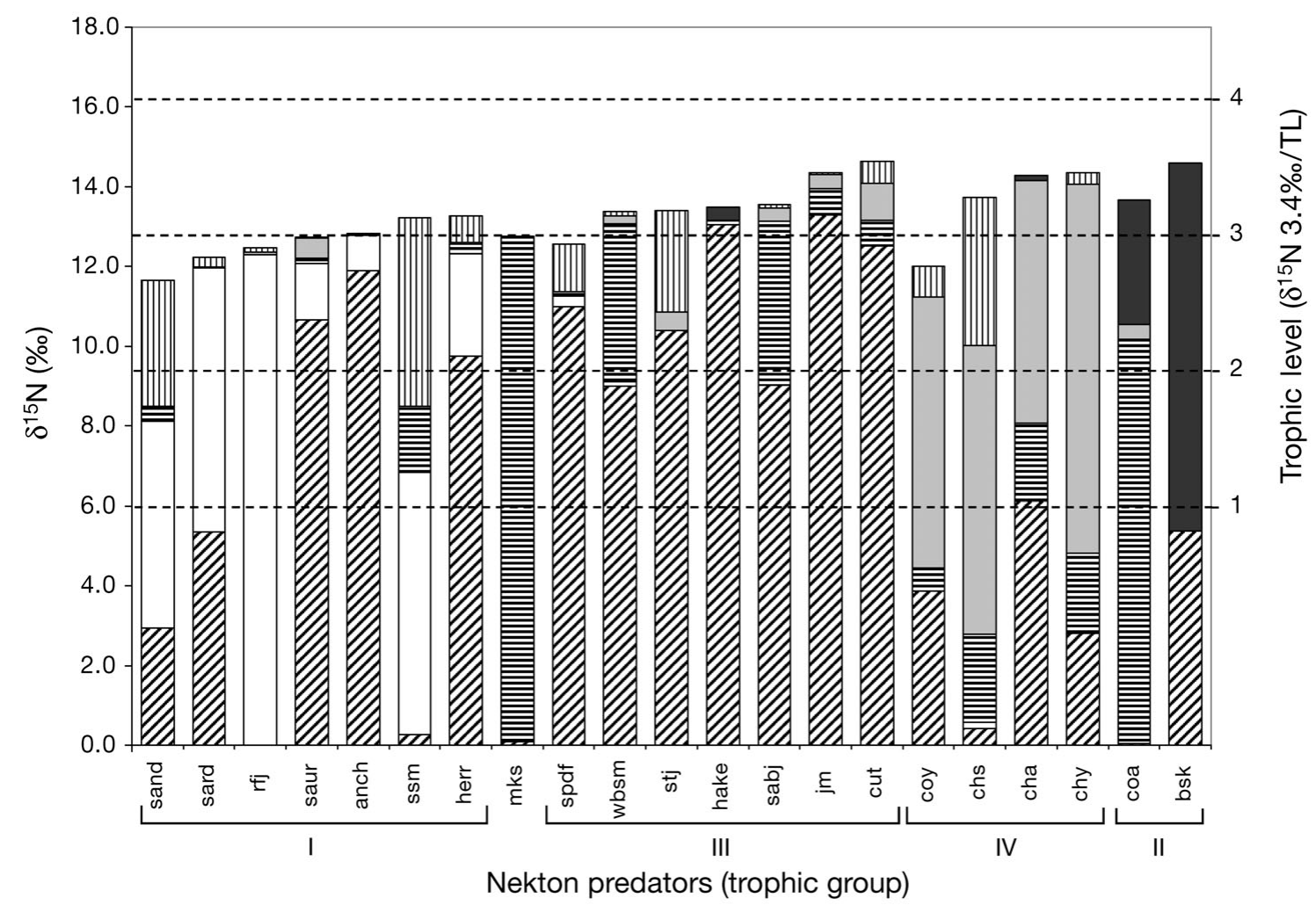

Fig. 3. Bar plot of nekton $\delta^{15} \mathrm{~N}$ and relative trophic level by trophic groups based on \% IRI of major prey to their diets (bars). Prey categories are the following: euphausiids (hatching), copepods (white), decapod larvae (horizontal lines), larval-juvenile fishes (grey), adult fish (black), and other (vertical lines). Trophic groups were derived from more detailed delineation of prey categories from agglomerative cluster analysis and are described in Table 2. See Table 1 for abbreviations of taxa 
Table 2. Summary of nekton diets, expressed as the mean percent index of relative importance (\% IRI), collected during June and August 2000 and 2002 off the Oregon and northern California coasts. Scientific names for nekton are given in Table 1. Trophic groups are derived from agglomerative hierarchical cluster analysis of nekton diets (\% IRI). All nekton taxa are adults unless otherwise notes by abbreviations. j: juvenile; sy: subyearling; y: yearling

\begin{tabular}{|c|c|c|c|c|c|c|c|c|c|c|c|}
\hline \multirow{2}{*}{$\begin{array}{l}\text { Trophic group } \\
\text { Nekton taxa (n) }\end{array}$} & \multirow[b]{2}{*}{$\begin{array}{l}\text { Appendic- } \\
\text { ularian }\end{array}$} & \multirow[b]{2}{*}{$\begin{array}{l}\text { Amphi- } \\
\text { pod }\end{array}$} & \multirow[b]{2}{*}{ Copepod } & \multicolumn{4}{|c|}{$\begin{array}{c}\text { Nekton prey }(\% 1 K 1)- \\
\text { Euphausiids } \\
\end{array}$} & \multirow[b]{2}{*}{$\begin{array}{c}\text { Decapod } \\
\text { larvae }\end{array}$} & \multirow[b]{2}{*}{$\begin{array}{l}\text { Cancer } \\
\text { magister } \\
\text { megalopae }\end{array}$} & \multicolumn{2}{|c|}{ Osteichthyes } \\
\hline & & & & Egg & Furcilia & $\begin{array}{c}\text { Thysanoessa } \\
\text { spinifera } \\
\text { adult }\end{array}$ & $\begin{array}{c}\text { Euphausia } \\
\text { pacifica } \\
\text { adult }\end{array}$ & & & $\begin{array}{l}\text { Larval- } \\
\text { juvenile }\end{array}$ & Adult \\
\hline Market squid (216) & & & 0.1 & 0.5 & & 0.2 & & 98.9 & & & \\
\hline \multicolumn{12}{|l|}{ Group I } \\
\hline Pacific sardine (268) & 1.6 & 0.4 & 53.1 & 34.2 & 0.2 & 2.1 & 6.4 & 0.1 & & 0.1 & \\
\hline Northern anchovy (10) & 0.1 & & 6.7 & 49.4 & & 42.0 & 0.3 & 0.1 & & 0.1 & \\
\hline Surf smelt (87) & 0.1 & 29.5 & 41.2 & 1.3 & 0.1 & 0.2 & & 9.9 & 0.1 & 0.3 & \\
\hline Pacific saury (180) & & 0.2 & 10.7 & 73.0 & & $<0.1$ & 6.9 & & 0.9 & 3.8 & \\
\hline Pacific sand lance, j (130) & & 27.0 & 44.3 & 18.0 & & 7.2 & & 3.0 & & & \\
\hline Rockfish, pelagic j (113) & 0.1 & 0.6 & 80.7 & & & & & & & & \\
\hline \multicolumn{12}{|l|}{ Group II } \\
\hline Coho salmon (69) & & & & & & 0.4 & $<0.1$ & 0.8 & 73.3 & 2.7 & 22.8 \\
\hline Blue shark (22) & & & & & & & 36.4 & & & & 62.3 \\
\hline \multicolumn{12}{|l|}{ Group III } \\
\hline Steelhead trout, j (70) & & 18.8 & & & & 20.8 & 56.5 & & & 3.5 & \\
\hline Cutthroat trout (11) & & 3.7 & & & & 83.5 & 2.0 & & 4.3 & 6.4 & \\
\hline Spiny dogfish (128) & & 9.3 & 2.0 & & & 72.5 & 14.1 & 1.0 & & & \\
\hline Pacific herring (286) & 0.2 & 4.7 & 19.1 & 2.7 & 1.0 & 64.7 & 4.5 & 1.7 & 0.1 & 0.4 & \\
\hline Pacific hake (72) & & & & & & 91.1 & 5.6 & 0.5 & 0.3 & & 2.5 \\
\hline Sablefish, pelagic j (21) & 0.0 & 0.6 & & & & 66.1 & 0.5 & 0.5 & 29.9 & 2.4 & \\
\hline Whitebait smelt (158) & & 0.8 & 0.8 & 0.9 & 16.8 & 48.1 & 0.9 & 29.3 & 0.1 & 1.4 & \\
\hline Jack mackerel (316) & & 0.3 & 0.1 & 0.2 & & 20.8 & 71.1 & 0.4 & 4.2 & 2.4 & \\
\hline \multicolumn{12}{|l|}{ Group IV } \\
\hline Chinook salmon, sy (85) & & 26.7 & 1.0 & & & 2.9 & 0.2 & 15.9 & 0.1 & 52.2 & \\
\hline Chinook salmon, y (200) & & 2.0 & & & & 17.2 & 2.4 & 13.8 & 0.2 & 64.4 & \\
\hline Chinook salmon, adult (1) & 132) & & & & & 37.0 & 5.9 & 2.1 & 11.6 & 42.6 & 0.8 \\
\hline Coho salmon, y (122) & & 6.4 & & & & 26.7 & 5.5 & 2.5 & 2.3 & 56.6 & \\
\hline
\end{tabular}

sisted of zooplankton. Specifically, blue shark consumed adult euphausiids (Euphausia pacifica, \% IRI = 36.4), and adult coho salmon consumed Cancer magister megalopae (\%IRI = 73.3). This was confirmed by their relative trophic positions based on $\delta^{15} \mathrm{~N}$, which were expressed as a mean TL of 3.6, a level intermediate between zooplanktivores and what would be considered full piscivores (TL 4.0).

Euphausiids were similarly important in the diets of the nekton trophic group (Group III) consisting of Pacific herring, Pacific hake Merluccius productus, spiny dogfish Squalus acanthias, juvenile steelhead Oncorhynchus mykiss, juvenile sablefish Anoplopoma fimbria, jack mackerel and cutthroat trout O. clarkii. All nekton in Group III had diets consisting predominantly of adult euphausiids (\%IRI > 60, Fig. 3, Table 2), with some proportion of the diet being brachyuran larvae (decapod larvae and Cancer magister megalopa) and to a lesser degree larval-juvenile fishes (with the exception of Pacific hake and spiny dogfish) and amphipods. This was expressed in $\delta^{15} \mathrm{~N}$ values, with a mean TL of 2.2 above zooplankton and 0.3 above larval-juvenile fish (mean $\delta^{15} \mathrm{~N}=11.8 \%$ ) (Table 1, Fig. 1).
The only nekton and juvenile fishes that were observed to consume almost entirely zooplankton were market squid (its own AHCA group, mean $\delta^{15} \mathrm{~N}=$ $12.8 \%$, TL 3.0), surf smelt, northern anchovy Engraulis mordax, Pacific sardine, Pacific saury, Pacific sand lance Ammodytes hexapterus and juvenile pelagic rockfish (Cluster Group I, mean TL $=2.9$ ). This group was also distinguished by its expression of $\delta^{15} \mathrm{~N}$ values within a single trophic level above zooplankton prey, which matched their diets of mostly small crustacean prey, such as euphausiid eggs, copepods and amphipods (Table 2, Fig. 2).

\section{DISCUSSION}

The combination of both $\delta^{15} \mathrm{~N}$ and $\delta^{13} \mathrm{C}$ and diet analysis provided one of the most comprehensive trophic analyses of a marine pelagic food web in an upwelling ecosystem. Most zooplankton and nekton were within the $\delta^{13} \mathrm{C}$ bounds of nearshore and offshore waters (Fig. 1, as defined in Miller et al. 2008), indicating our analyses well covered the true shelf ecosystem. 
From $\delta^{15} \mathrm{~N}$ the total number of trophic levels from POM to top trophic level fishes was 3.8, which is in the lower range of previous assessments of TLs within marine pelagic systems (Vander Zanden \& Fetzer 2007) and coastal upwelling zones, based either on stomach content (Yodzis 1998) or stable isotope analysis (3.7 TL, Bode et al. 2007). The addition of northern sea lions from the same region as our study (Sydeman et al. 1997) added an additional trophic level (total, 5.0). Other potential top-level predators of the California Current, such as adult white sharks Carcharodon carcharias or killer whales Orcinus orca, would probably not have added another trophic level. White sharks mostly consume a mixed diet of fish and to some degree marine mammals and have been found to be trophically indistinguishable from top predator marine mammals (Cortés 1999). Similarly, resident or transient killer whales from the same general region $\left(\delta^{15} \mathrm{~N}\right.$ approximately $17.0 \%$, Herman et al. 2005) have shown lower $\delta^{15} \mathrm{~N}$ values relative to northern sea lions (19.8\%o, Sydeman et al. 1997). The high $\delta^{15} \mathrm{~N}$ of northern sea lions reported by Sydeman et al. (1997) may be due to a greater dependence on benthic or demersal species that are possibly more picivorous, but also have a higher $\delta^{15} \mathrm{~N}_{\text {base }}$ due to nitrogen sources arriving from processes of oxidation and denitrification. Bosley et al. (2004) observed that many adult rockfishes and flatfishes in the NCC had $\delta^{15} \mathrm{~N}$ values between 16 and $17 \%$, approximately one TL from northern sea lions observed by Sydeman et al. (1997).

During the time of our study an overriding characteristic of the NCC food web was that nekton were feeding at multiple trophic levels, with most (65\%) consuming a mixed diet of zooplankton, ichthyoplankton and, to a lesser extent, other nekton species (Fig. 3). This was reflected in $\delta^{15} \mathrm{~N}$ values that were intermediate between what would be considered full zooplanktivores (TL 3) and full piscivores (TL 4, Figs. 1 \& 3). However, some distinct trophic groups were observed. All crustacean zooplankton were within a short trophic range of approximately 2.0 and $2.3 \mathrm{TL}$, and the nekton feeding exclusively on zooplankton in the diet analyses were between 2.7 and 3.1 TL (Fig. 3). Based upon $\delta^{15} \mathrm{~N}$ analysis of the food web off the Iberian Peninsula, Bode et al. (2007) showed rather distinct differences between zooplankton, fish, and the common dolphin Delphinus delphinus. Most of the 10 fish species they examined were at nonintegral trophic levels and relatively low on the food web (TL of 3.4 to 3.7). Other than Bode et al. (2007), surprisingly few studies have applied stable isotopes on an ecosystem scale for marine upwelling ecosystems, with most occuring from other systems, such as the Tasman Sea, Australia (Davenport \& Bax 2002), northeast Atlantic Ocean (Sherwood \& Rose 2005), Arctic Ocean (Hobson \&
Welch 1992), Weddell Sea (Rau et al. 1992) and the Patagonian shelf (Ciancio et al. 2008) or focus on only a few select taxa (Sholto-Douglas et al. 1991, Bode et al. 2007). Given the importance of EBC systems to fisheries and their apparent responses to shifts in climate (Chavez et al. 2003) and bottom-up control (Ware \& Thomson 2005), further application of stable isotopes may better reveal trophic links and processes that drive ecosystem dynamics. For example, a comparison of large marine ecosystems using $\delta^{15} \mathrm{~N}$ as a measure of relative trophic level among similar taxa could help clarify the factors that determine food chain length and omnivory, and ultimately stablility. Diet analyses could furthermore provide greater insight into what prey are contributing to predator isotopic values.

Of the zooplankton prey we observed in nekton diets, euphausiids were by far the most prevalent and widely consumed across multiple nekton trophic groups. For example, although euphausiids were dominant in the diets of Cluster Group III (Table 2), they were also prevalent in most other groups, including larger nekton, such as adult blue sharks (\% IRI = 36.0, Fig. 3). The broad contribution of adult euphausiids as prey across many trophic level species caused considerable mixing of different trophic groups based on AHCA of diet data. That is, trophic aggregations by diet and AHCA only matched moderately when plotted in isotopic space, particularly for nekton consuming adult euphausiids and other prey. Euphausiid eggs and furcilia were also consumed by several adult and juvenile nekton species, indicating the integral contribution of euphausiids to multiple trophic levels.

The importance of euphausiids as prey for pelagic nekton has previously been observed from the NCC (Brodeur \& Pearcy 1992, Tanasichuk 1999), other EBC upwelling zones (van der Lingen 2002, Antezana 2010) and other productive ecosystems (Rau et al. 1992, Young et al. 1993). Euphausiids can be a sizable fraction of the zooplankton community biomass (Lavaniegos \& Ohman 2007), have a relatively large body size and have a tendency to form large swarms, all of which make them more available prey to a range of fish and other nekton species. Euphausiids are therefore an important link between primary production and the nekton community in some ecosystems. This relationship, however, is not straightforward because euphausiids can feed on phytoplankton and other mesozooplankton (Stuart \& Pillar 1990) and can exhibit ontogenetic shifts in diet (Rau et al. 1991), which may diffuse apparent bottom-up effects from primary production alone. Our results showed that the dominant euphausiid, Thysanoessa spinifera, displayed higher $\delta^{15} \mathrm{~N}$ values than did most other zooplankton, indicating some capacity for feeding at different trophic levels. This capacity has been observed in other 
euphausiid species (Rau et al. 1991, Schmidt et al. 2006). Further investigation using both dietary content and stable isotope analyses could better reveal these trophic relationships.

The trophic patterns we observed were inconsistent with conventions of top-down and 'wasp-waist' control (Cury et al. 2000, see also Fréon et al. 2009), both of which imply a somewhat more linear food chain. In the NCC system, bottom-up control is more likely due to the influence of strong seasonal coastal upwelling and subsequent production during spring and summer months. Substantial interannual to interdecadal changes in the timing, persistence and intensity of upwelling, and the relationship between these changes and plankton production (Checkley \& Barth 2009) may also imply bottom-up control. During favorable conditions, high consumption of euphausiids by nekton may not significantly deplete euphausiid biomass; however, this may shift in years of low prey abundance, such as during El Niño events, where prey become more limiting and nekton subsequently shift to other available prey (Brodeur \& Pearcy 1992).

Although simple, the concept of bottom-up control does not integrate important aspects of food web structure that may influence how energy is dispersed, as in

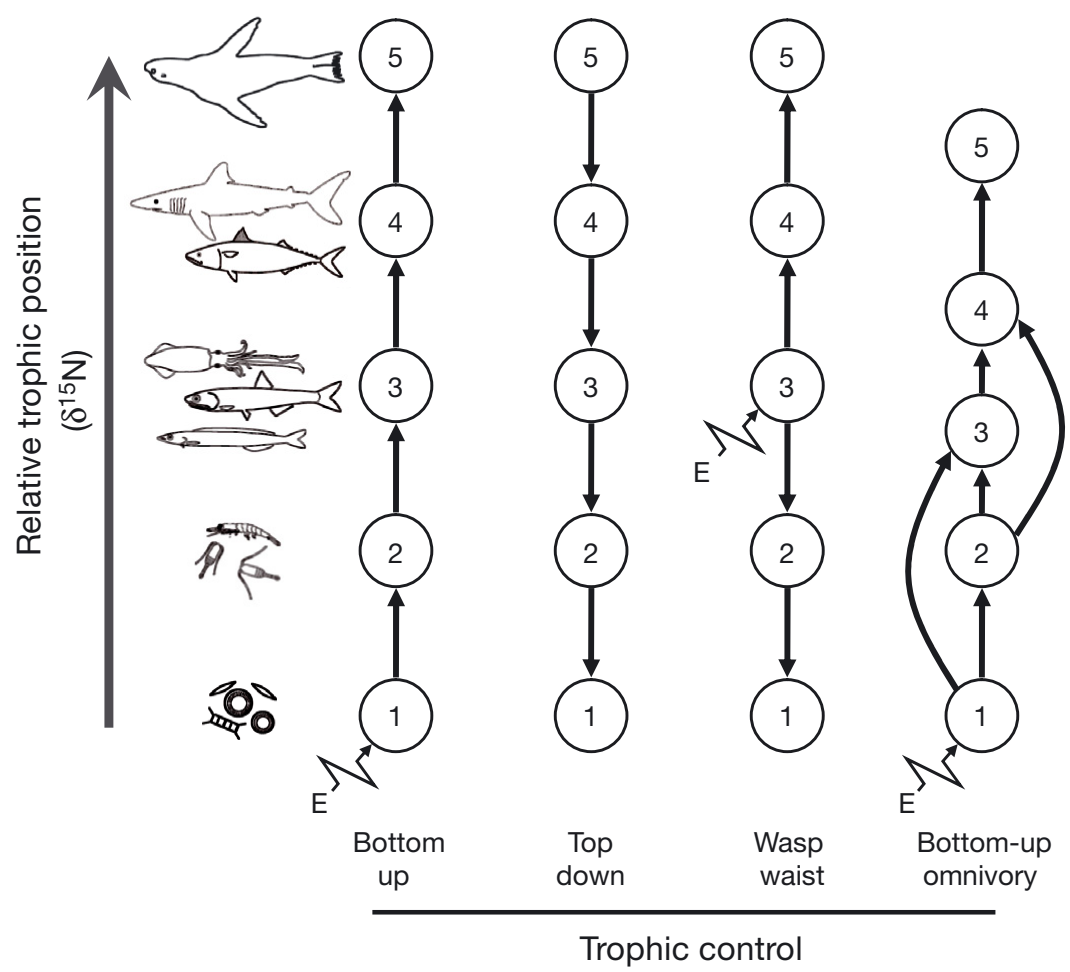

Fig. 4. Model schematics of trophic controls and position of relative trophic levels by $\delta^{15} \mathrm{~N}$ analysis of marine pelagic ecosystems. Circles are hypothetical trophic levels, as noted by number, and arrows represent the direction of trophic flow. Environmental forcing is noted as ' $\mathrm{E}$ ' with jagged arrow the case of omnivory in which an organism feeds at more than one TL. Given the significance of bottom-up control and prevalence of omnivory in the NCC, a more realistic model incorporating both characteristics, termed bottom-up omnivory (BUO, Fig. 4), is introduced here. In BUO, primary production in the form of large diatoms may favor an abundance of larger, more conspicuous zooplankton prey, such as euphausiids, which may in turn be more available to a greater range of predatory nekton. This results in a more truncated and reticulated food web with a lower predator-prey size ratio wherein larger predators feed relatively closer to secondary production rather than to their adjacent lower trophic level. For example, Rau et al. (1992) observed a limited trophic range and high overlap among $\delta^{15} \mathrm{~N}$ values of fish from the Weddell Sea. This was consistent with previous studies indicating the importance of euphausiids (i.e. Euphausia superba) as a major prey resource in this system. Moreover, from the Iberian Peninsula upwelling system, Bode et al. (2007) observed high variability in the predator-prey size ratio, and they attributed this variability to larger fish feeding relatively lower on the food web. Although we did not specifically look at size ratios of predators and prey, there was considerable trophic overlap between nekton of variable sizes based on both $\delta^{15} \mathrm{~N}$ and diet content. For example, adult blue shark and adult coho salmon, both of which were the largest organisms in our study, were within the isotopic and dietary range of small fishes such as Pacific herring, whitebait smelt and cutthroat trout.

The presence of omnivory in real food webs has been a continuing debate in ecology (Polis \& Strong 1996, Williams \& Martinez 2004). Omnivory occurs across many types of food webs, and in a comparison of its relative importance between terrestrial and aquatic systems, Thompson et al. (2007) found that marine pelagic ecosystems expressed a greater degree of omnivory than did other systems. However, empirical data specifically related to continental shelf pelagic ecosystems continue to be limited. Thus, meaningful comparisons between marine pelagic systems remain limited to those that focus on factors attributed to trophic structure (e.g. Thompson et al. 2007, Vander Zanden \& Fetzer 2007). A comparison of large marine ecosystems using $\delta^{15} \mathrm{~N}$ as a 
measure of relative trophic level among similar taxa, similar to trophic comparisons by Post et al. (2000) between lake ecosystems, could help clarify the factors that determine food chain length and omnivory, and ultimately stability of marine food webs. The question of whether EBC food webs have greater omnivory is complex because the high production in these systems theoretically fuels a longer food chain length, which may foster greater omnivory in species from higher trophic levels due to topological constraints (Polis \& Strong 1996, Thompson et al. 2007). This was probably not the case here because omnivory was attributed to only a few highly dominant prey, in particular adult euphausiids, which provide high resource availability across many species that previously may have been considered to be in different trophic levels.

Our study was limited to POM, meso- and macrozooplankton and the pelagic nekton, and did not include benthic organisms, other marine mammals or seabirds. Epibenthic and some benthic fish, as well as mesopelagic myctophids that were not analyzed in this study, undoubtedly play an important role in the food web of this region. The vast number of species and individual behaviors remains an additional factor to contend with. Also, stable isotopes are a temporal integration of an organism's past feeding and one might reasonably assume that our sampling should have included seasonal measurements to obtain a longer temporal integration of the $\delta^{15} \mathrm{~N}_{\text {base, }}$ and thus a more accurate assesment of trophic level fractionation (Jennings et al. 2008). This was unnecessary because isotopic shifts in poikilotherms occur almost entirely through added tissue growth (MacAvoy et al. 2001), and it is well known that growth in boreal marine fishes occurs almost entirely within the window of seasonal production (spring to autumn). Our measurement of the $\delta^{15} \mathrm{~N}_{\text {base }}$ and use of $3.4 \%$ for $\Delta \delta^{15} \mathrm{~N}$ are therefore probably reasonable estimates of the base of the food web contributing to the food web structure of the NCC ecosystem. We did observe significant seasonal and interannual differences in $\delta^{15} \mathrm{~N}$ and $\delta^{13} \mathrm{C}_{\mathrm{TL}}^{\prime}$ in several nekton species; however, the magnitude of difference was generally small (0.3 to $1.0 \%$ ) and there was no consistent trend. This may be due to the fact that although adequate sample numbers were obtained for statistical comparison, some nekton (e.g. surf smelt and Pacific saury) were only collected from 2 or 3 hauls, which would have greatly constrained variation in the isotope values. For market squid, which showed significant seasonal and interannual differences, samples were collected from numerous hauls and over a broad spatial scale, and it is possible that these differences may be real because market squid have extremely high growth rates and may express temporally short feeding pulses relative to slower growing fishes.
There were several species with unexpected $\delta^{15} \mathrm{~N}$ values considering their diet (Fig. 2). The relative trophic levels of the salmonids (juvenile-adult) and blue shark were low considering the proportional contribution of fish (larval-adult) to the diet, suggesting that diet analyses may overestimate the relative trophic position of some species, especially those consuming more fish (Fig. 3). Isotope analysis of juvenile chum salmon Oncorhynchus keta expressed some of the highest $\delta^{15} \mathrm{~N}$ values, even though they were one of the smallest by body mass of nekton analyzed. This could have resulted from a recent release from a local hatchery where they are fed diets consisting mainly of fish meal, or possibly because juvenile chum salmon are known to feed on ctenophores, tunicates and larval-juvenile fishes in coastal waters (Brodeur et al. 2007), which are predators on other zooplankton.

Our study occurred during years of high upwelling intensity and during the cool phase of the PDO (Mantua et al. 1997, Peterson \& Schwing 2003), which would favor higher primary production and euphausiid biomass and may explain the low seasonal and interannual variation in $\delta^{15} \mathrm{~N}$ and $\delta^{13} \mathrm{C}_{\mathrm{TL}}^{\prime}$. The NCC system exhibits interannual and interdecadal shifts in productivity and species composition, which are mostly associated with El Niño and La Niña events, and over greater time scales, with interdecadal shifts in production (Chavez et al. 2003, Peterson \& Schwing 2003). Substantial insights into the importance of productivity on dietary overlap, particularly with respect to euphausiids, would be gained if a similar study were conducted during a low productivity period. Based on the observations of Brodeur \& Pearcy (1992) that showed differences in food web structure between El Niño (warm, low production) and La Niña (cool, high production) periods during the 1980s, dietary overlap would decrease and the presence of euphausiids in the diets would also be in decline during low productivity years. We would therefore expect isotope ratios of trophic groups or specific species to be more separated in isotopic space and the trophic levels of some nekton to expand upward. The importance of this observation is that it confirms the mechanisms by which energy flows through food webs in the advent of high or low productive years from upwelling intensity and persistence, a factor potentially tied to global climate change.

To bring together diet and isotope results, we attempted to apply isotopic mixing models (Phillips 2001) to individual species and their prey; however, in several cases the main model assumption was not met because $\delta^{13} \mathrm{C}^{\prime}$ TL and $\delta^{15} \mathrm{~N}$ isotope signatures of the prey were outside the isotopic range of the predator. This could be attributed to a number of factors, such as the existence of an unknown trophic fractionation factor of 
$\Delta \delta^{13} \mathrm{C}$, potential problems in obtaining isotope values from all prey and the importance of donor control to the system. This latter aspect was highly probable given the size of the NCC food web and its immeasurable contributions from external sources, such as subarctic transient upwelled water. This and other contributions, including epibenthic prey, migration of larger nekton species and intrusion of offshore waters, are obviously beyond control in any study of an open ecosystem such as the NCC.

Nevertheless, our analysis captured much of the trophic variability using $\delta^{15} \mathrm{~N}$ and, in combination with $\delta^{13} \mathrm{C}_{\mathrm{TL}}^{\prime}$ and shelf-slope delineation from Miller et al. (2008, Fig. 2) describing the nearshore-offshore distribution of nekton, provides an effective measure for assessing the spatial and trophic overlap within this pelagic ecosystem.

Acknowledgements. This study was funded by the US GLOBEC NE Pacific Program, the NOAA Nortwest Fisheries Science Center, the Bonneville Power Administration, the Global Center of Excellence, Center for Marine Environmental Studies, Ehime University and the Bill Wick Marine Fisheries Award. We thank the late P. Eldridge (US Environmental Protection Agency), W. Sydeman (Farallon Institute for Advanced Ecosystem Research), T. Francis, E. Casillas (NOAA Fisheries) and 2 anonymous reviewers for helpful discussions and comments on the research and manuscript and the scientists and crew who assisted in sampling. Special thanks are due to M. Kubo and K. Turk for help with isotope analysis. This paper is dedicated to Peter Eldridge.

\section{LITERATURE CITED}

Ainley DG, Spear LB, Allen SG (1996) Variation in the diet of Cassin's Auklet reveals spatial, seasonal, and decadal occurrence patterns of euphausiids off California, USA. Mar Ecol Prog Ser 137:1-10

Antezana T (2010) Euphausia mucronata: a keystone herbivore and prey of the Humboldt Current System. Deep-Sea Res II 57:652-662

Bode AP, Alvarez-Ossorio MT, Cunha ME, Garrido S and others (2007) Stable nitrogen isotope studies of the pelagic food web on the Atlantic shelf of the Iberian Penninsula. Prog Oceanogr 74:115-131

Bosley KL, Lavelle JW, Brodeur RD, Wakefield WW, Emmett RL, Baker ET, Rehmke KM (2004) Biological and physical processes in and around Astoria Submarine Canyon, Oregon, USA. J Mar Syst 50:21-37

Brodeur RD, Pearcy WG (1992) Effects of environmental variability on trophic interactions and food web structure in a pelagic upwelling ecosystem. Mar Ecol Prog Ser 84: 101-119

Brodeur RD, Pearcy WG, Ralston S (2003) Abundance and distribution patterns of nekton and micronekton in the northern California Current transition zone. J Oceanogr 59:515-535

Brodeur RD, Fisher JP, Emmett RL, Morgan CA, Casillas E (2005) Species composition and community structure of pelagic nekton off Oregon and Washington under variable oceanographic conditions. Mar Ecol Prog Ser 298:41-57
Brodeur RD, Daly EA, Sturdevant MV, Miller TW and others (2007) Regional comparisons of juvenile salmon feeding in coastal marine waters off the west coast of North America. Am Fish Soc Symp 57:183-203

Chavez FP, Ryan J, Lluch-Cota SE, Niquen MC (2003) From anchovies to sardines and back: multidecadal change in the Pacific Ocean. Science 299:217-221

Checkley DM Jr, Barth JA (2009) Patterns and processes in the California Current System. Prog Oceanogr 83:49-64

Ciancio JE, Pascual MA, Botto F, Frere E, Iribarne O (2008) Trophic relationships of exotic anadromous salmonids in the southern Patagonian Shelf as inferred by stable isotopes. Limnol Oceanogr 53:788-798

Cortés E (1997) A critical review of methods of studying fish feeding based on analysis of stomach contents: application to elasmobranch fishes. Can J Fish Aquat Sci 54:726-738

Cortés E (1999) Standardized diet compositions and trophic levels of sharks. ICES J Mar Sci 56:707-717

Cury P, Shannon L (2004) Regime shifts in upwelling ecosystems: observed changes and possible mechanisms in the northern and southern Benguela. Prog Oceanogr 60: 223-243

Cury P, Roy C, Faure V (1998) Environmental constraints and pelagic fisheries in upwelling areas: the Peruvian puzzle. S Afr J Mar Sci 19:159-167

Cury $\mathrm{P}$, Bakun A, Crawford RJM, Jarre-Teichmann A, Quinones R, Shannon LJ, Verheye HM (2000) Small pelagics in upwelling systems: patterns of interaction and structural changes in 'wasp-waist' ecosystems. ICES J Mar Sci 57:603-618

> Davenport SR, Bax NJ (2002) A trophic study of a marine ecosystem off southeastern Australia using stable isotopes of carbon and nitrogen. Can J Fish Aquat Sci 59:514-530

> Emmett RL, Krutzikowsky GK, Bentley P (2006) Abundance and distribution of pelagic piscivorous fishes in the Columbia River plume during spring/early summer 1998-2003: relationship to oceanographic conditions, forage fishes, and juvenile salmonids. Prog Oceanogr 68: $1-26$

Fréon P, Arístegui J, Bertrand A, Crawford RJM and others (2009) Functional group biodiversity in Eastern Boundary Upwelling Ecosystems questions the wasp-waist trophic structure. Prog Oceanogr 83:97-106

- Herman DP, Burrows DG, Wade PR, Durban JW and others (2005) Feeding ecology of eastern North Pacific killer whales Orcinus orca from fatty acid, stable isotope and organochlorine analyses of blubber biopsies. Mar Ecol Prog Ser 302:275-291

Hobson KA, Welch HE (1992) Determination of trophic relationships within a high Arctic marine food web using $\delta^{13} \mathrm{C}$ and $\delta^{15} \mathrm{~N}$ analysis. Mar Ecol Prog Ser 84:9-18

Hutchings L, van der Lingen CD, Shannon LJ, Crawford RJM and others (2009) The Benguela Current: an ecosystem of four components. Prog Oceanogr 83:15-32

Jennings S, Maxwell TAD, Schratzberger M, Milligan SP (2008) Body-size dependent temporal variations in nitrogen stable isotope ratios in food webs. Mar Ecol Prog Ser 370:199-206

> Keister JE, Johnson TB, Morgan CA, Peterson WT (2005) Biological indicators of the timing and direction of warmwater advection during the 1997/98 El Niño off the central Oregon coast, USA. Mar Ecol Prog Ser 295:43-48

> Lavaniegos BE, Ohman MD (2007) Coherence of long-term variations of zooplankton in two sectors of the California Current System. Prog Oceanogr 75:42-69

> MacAvoy SE, Macko SA, Garman GC (2001) Isotopic turnover in aquatic predators: quantifying the exploitation of 
migratory prey. Can J Fish Aquat Sci 58:923-932

Mackas DL, Batten S, Trudel M (2007) Effects on zooplankton of a warmer ocean: recent evidence from the Northeast Pacific. Prog Oceanogr 75:223-252

Mantua NJ, Hare SR, Zhang Y, Wallace JM, Francis RC (1997) A Pacific decadal climate oscillation with impacts on salmon. Bull Am Meteorol Soc 78:1069-1079

Miller TW, Brodeur RD (2007) Diet of and trophic relationships among dominant marine nekton within the Northern California Current ecosystem. Fish Bull 105:548-559

Miller TW, Brodeur RD, Rau HG (2008) Carbon stable isotopes reveal relative contribution of shelf-slope production to the Northern California Current pelagic community. Limnol Oceanogr 53:1493-1503

Peterson BJ, Fry B (1987) Stable isotopes in ecosystem studies. Annu Rev Ecol Syst 18:293-320

Peterson WT, Schwing FB (2003) A new climate regime in northeast Pacific ecosystems. Geophys Res Lett 30,1896 doi:10.1029/2003GL017528

Phillips DL (2001) Mixing models in analyses of diet using multiple stable isotopes: a critique. Oecologia 127:166-170

Pinkas L, Oliphant MS, Iverson ILK (1971) Food habits of albacore, bluefin tuna, and bonito in California waters. Calif Fish Game Fish Bull 152:1-105

Polis GA, Strong DR (1996) Food web complexity and community dynamics. Am Nat 147:813-846

Post DM (2002) Using stable isotopes to estimate trophic position: models, methods, and assumptions. Ecology 83: 703-718

Post DM, Pace ML, Hairston NG (2000) Ecosystem size determines food-chain length in lakes. Nature 405:1047-1049

Rau GH, Hopkins TL, Torres JJ (1991) ${ }^{15} \mathrm{~N} /{ }^{14} \mathrm{~N}$ and ${ }^{13} \mathrm{C} /{ }^{12} \mathrm{C}$ in Weddell Sea invertebrates: implications for feeding diversity. Mar Ecol Prog Ser 77:1-6

Rau GH, Ainley DG, Bengtson JL, Torres JJ, Hopkins TL (1992) ${ }^{15} \mathrm{~N} /{ }^{14} \mathrm{~N}$ and ${ }^{13} \mathrm{C} /{ }^{12} \mathrm{C}$ in Weddell Sea birds, seals, and fish: implications for diet and trophic structure. Mar Ecol Prog Ser 84:1-8

Roemmich D, McGowan J (1995) Climate warming and the decline of zooplankton in the California Current. Science 267:1324-1326

Schmidt KA, Atkinson A, Petzke KJ, Voss M, Pond DW (2006) Protozoans as a food source for Antarctic krill, Euphausia superba: complementary insights from stomach content, fatty acids, and stable isotopes. Limnol Oceanogr 51: $2409-2427$

Shannon LJ, Moloneya CL, Jarre A, Field JG (2003) Trophic flows in the southern Benguela during the 1980s and 1990s. J Mar Syst 39:83-116

Sherwood GD, Rose GA (2005) Stable isotope analysis of some representative fish and invertebrates of the New-

Editorial responsibility: Yves Cherel,

Villiers-en-Bois, France foundland and Labrador continental shelf food web. Estuar Coast Shelf Sci 63:537-549

Sholto-Douglas AD, Field JG, James AG, Merwe NJ (1991) ${ }^{13} \mathrm{C} /{ }^{12} \mathrm{C}$ and ${ }^{15} \mathrm{~N} /{ }^{14} \mathrm{~N}$ isotope ratios in the Southern Benguela Ecosystem: indicators of food web relationships among different size-classes of plankton and pelagic fish; differences between fish muscle and bone collagen tissues. Mar Ecol Prog Ser 78:23-31

Smith RL, Huyer A, Fleischbein J (2001) The coastal ocean off Oregon from 1961 to 2000: Is there evidence of climate change or only of Los Niños? Prog Oceanogr 49:63-93

Stuart V, Pillar SC (1990) Diel grazing patterns of all ontogenetic stages of Euphausia lucens and in situ predation rates on copepods in the southern Benguela upwelling region. Mar Ecol Prog Ser 64:227-241

> Sydeman WJ, Hobson KA, Pyle P, McLaren EB (1997) Trophic relationships among seabirds in central California: combined stable isotope and conventional dietary approach. Condor 99:327-336

Tam J, Purca S, Duarte O, Blaskovic V, Espinoza P (2006) Changes in the diet of hake associated with El Niño 1997-1998 in the northern Humboldt Current ecosystem. Adv Geosci 6:63-67

Tanasichuk RW (1999) Interannual variation in the availability and utilization of euphausiids as prey for Pacific hake (Merluccius productus) along the south-west coast of Vancouver Island. Fish Oceanogr 8:150-156

Thompson RM, Hemberg M, Starzomski BM, Shurin JB (2007) Trophic levels and trophic tangles: the prevalence of omnivory in real food webs. Ecology 88:612-617

van der Lingen CD (2002) Diet of sardine Sardinops sagax in the southern Benguela upwelling ecosystem. S Afr J Mar Sci 24:301-316

> Vander Zanden MJ, Fetzer WW (2007) Global patterns of aquatic food chain length. Oikos 116:1378-1388

Ware DM, Thomson RE (2005) Bottom-up ecosystem trophic dynamics determine fish production in the northeast Pacific. Science 308:1280-1284

Williams RJ, Martinez ND (2004) Limits to trophic levels and omnivory in complex food webs: theory and data. Am Nat 163:458-468

Yodzis P (1998) Local trophodynamics and the interaction of marine mammals and fisheries in the Benguela ecosystem. J Anim Ecol 67:635-658

> Yodzis P (2000) Diffuse effects in food webs. Ecology 81: 261-266

Young JW, Jordan AR, Bobbi C, Johannes RE, Haskard K, Pullen G (1993) Seasonal and interannual variability in krill (Nyctiphanes australis) stocks and their relationship to the fishery for jack mackerel (Trachurus declivis) off eastern Tasmania, Australia. Mar Biol 116:9-18

Submitted: May 14, 2010; Accepted: October 14, 2010

Proofs received from author(s): December 6, 2010 